\title{
Editorial: Legacy Phosphorus in Agriculture: Role of Past Management and Perspectives for the Future
}

\author{
Luke Gatiboni $^{1 \star}$, Gustavo Brunetto ${ }^{2}$, Paulo S. Pavinato ${ }^{3}$ and Timothy S. George ${ }^{4}$ \\ ${ }^{1}$ Department of Crop and Soil Sciences, North Carolina State University, Raleigh, NC, United States, ${ }^{2}$ Department of Soils, Federal \\ University of Santa Maria, Santa Maria, Brazil, ${ }^{3}$ Department of Soil Science, College of Agriculture Luiz de Queiroz, University of \\ São Paulo, Piracicaba, Brazil, ${ }^{4}$ Department of Ecological Sciences, The James Hutton Institute, Dundee, United Kingdom
}

Keywords: legacy phosphorus, agriculture, fertilizers, phosphates, soil fertility

Editorial on the Research Topic

Legacy Phosphorus in Agriculture: Role of Past Management and Perspectives for the Future

\section{OPEN ACCESS}

Edited and reviewed by: Valerio Acocella,

Roma Tre University, Italy

*Correspondence: Luke Gatiboni luke_gatiboni@ncsu.edu

Specialty section:

This article was submitted to Soil Processes, a section of the journal Frontiers in Earth Sceience

Received: 21 October 2020 Accepted: 04 November 2020 Published: 20 November 2020

Citation:

Gatiboni L, Brunetto G, Pavinato PS and George TS (2020) Editorial: Legacy Phosphorus in Agriculture: Role of Past Management and

Perspectives for the Future.

Front. Earth Sci. 8:619935.

doi: 10.3389/feart.2020.619935

\section{INTRODUCTION}

Phosphorus (P) is an essential nutrient for higher plants and the primary source of this nutrient is from soil. However, many soils globally are $\mathrm{P}$ deficient and phosphate fertilizer input is necessary for agricultural production. Part of applied $\mathrm{P}$ is accumulated in the soil in non-labile forms due to its chemical high-affinity reactions and occlusion to soil minerals and organic matter, known as "legacy P." Continued fertilizer applications beyond plant requirements have led to a build-up of legacy P in soils. Unfortunately, this imbalanced P input: output ratio is necessary in most cases to maintain satisfactory yields in conventional agricultural systems, ultimately promoting environmental concerns such as eutrophication, if transferred to water bodies. Moreover, as economically viable phosphate rock is finite and non-renewable, agricultural systems need to be redesigned for a better balance (input $=$ output) of $\mathrm{P}$ and postpone a future scarcity scenario.

In this Research Topic we have collected contributions from North America, South America and Australasia, highlighting the impacts of legacy $\mathrm{P}$ on agricultural and environmental sustainability. Moreover, some agronomic approaches are described which have the potential to enable the use of legacy P more effectively and allow more accurate predictions on the ability to reduce legacy $\mathrm{P}$ on the environment, while maintaining sustainable production of crops.

\section{IMPACT OF LEGACY-P AS SOURCE OF P TO CROPS}

In a long-term (45 years) land use assessment, Zhang et al. (2020a) demonstrate that cropping systems, even with and without fertilization, lead to increased conversion of organic legacy $\mathrm{P}$ into inorganic forms compared to native land-use. Cropping without fertilization reduced legacy $\mathrm{P}$ significantly, while cropping with fertilization maintained or increased legacy $\mathrm{P}$, particularly in pastures. This work suggests that fertilization leads to soil $\mathrm{P}$ accumulation and increase risk of environmental degradation. This was also confirmed in Zhang et al. (2020b) where after 11 years of cultivation, in which the yield and $\mathrm{P}$ uptake by the maize-soybean crops was not affected by withdrawal of $\mathrm{P}$ fertilizer down to the critical level, legacy $\mathrm{P}$ was reduced by $3.3 \mathrm{mg} \mathrm{kg}^{-1} \mathrm{yr}^{-1}$. In fact the reliance on legacy $\mathrm{P}$ improved farmers' economic margins and reduced the soil test $\mathrm{P}$ levels to safe levels for surrounding catchments. 


\section{IMPACTS OF AGRONOMIC MANAGEMENT ON LEGACY $P$}

\section{Soil Management Impacts}

The impact of cover crops and fertilizer source on legacy P was investigated by Soltanghesi et al. (2020), demonstrating that cover crops are able to improve soil $\mathrm{P}$ availability for the following cash crop, but the effectiveness was dependent on the species and the source of $\mathrm{P}$ added, with rock phosphate being more effective compared to soluble P source. Nunes et al. (2020) assessed a longterm (17 years) tillage trial and demonstrated that the combination of fertilizer source and placement had an impact on the distribution and accumulation of legacy P. Under no-till, $\mathrm{P}$ tended to accumulate at the surface, in both labile and mod-labile forms, while conventional tillage tended to dilute $\mathrm{P}$ down the profile, with a more pronounced effect on legacy $\mathrm{P}$ for rock phosphate. This has impacts on both the availability of $\mathrm{P}$ to the crop and the potential transfer to the wider environment by erosion or runoff.

\section{Fertilization With Alternative Nutrient Sources}

Addition of sewage sludge to forestry can both reduce the amount of mineral fertiliser needed and increase labile $\mathrm{P}$ relative to nonlabile $\mathrm{P}$, suggesting an improved availability and use of legacy $\mathrm{P}$, as proved by Abreu-Junior et al. (2020). While, Zhang X et al. (2020) demonstrated that papermill biosolids (PB) could be used as an effective alternative P-fertiliser, as its addition increased the labile $\mathrm{P}$ fractions in soil. However, only around a third of the total $\mathrm{P}$ added in the $\mathrm{PB}$ was recovered in the labile pool, suggesting a substantial addition to the legacy $\mathrm{P}$ as well. Taken together these findings suggest that alternative bulky organic waste products may be useful fertilisers. However, little is known about their short and long-term impact on P cycling and legacy.

\section{Addition of Biologicals}

The addition of $\mathrm{P}$ solubilizing bacteria (PSB) showed increase in PUE by maize, although some PSB's were more effective than others, as presented by Pereira et al. (2020). Similarly, Rosa et al. (2020) demonstrate that PSB increased PUE of sugarcane and led to more efficient use of fertilisers. In addition, both papers confirm that combinations of bacteria may be even more effective than single species, suggesting that PSBs may reduce the soil legacy $\mathrm{P}$ by increasing PUE from fertilizer, improving long-term efficiency in the production system.

\section{IMPACTS OF REDUCING FERTILIZATION ON LEGACY $P$}

One of the key ways to reduce legacy $\mathrm{P}$ is to reduce fertiliser input. While this practice may reduce environmental risk, it needs to sustain cropping production. Messiga et al. (2020) demonstrate that $\mathrm{P}$ added as a "starter" in maize production systems can be reduced by up to $75 \%$ without effecting yield, as crops rely more on legacy $\mathrm{P}$ in over-fertilized soils. Changing this agronomic practice will reduce the risk of $\mathrm{P}$ transfer to watercourses. This approach is investigated more in Tyson et al. (2020) who describe a model which is able to predict the impact of reducing $\mathrm{P}$ fertilization rates on achieving agronomic optimum $\mathrm{P}$ concentrations in pasture systems and demonstrates that it is likely to take decades to bring the legacy $\mathrm{P}$ down in over-fertilized pasture soils. Likewise, McDowell et al. (2020) demonstrates that it is possible to reduce legacy $\mathrm{P}$ by reducing $\mathrm{P}$ fertiliser inputs, being possible to achieve the optimal agronomic targets in a relatively short time, one year for most soils in New Zealand. However, they highlight that the ability to reach the environmental target for reduced pollution of water can take several decades and may not compliment the aim of maintaining agricultural output.

\section{PROSPECTS FOR FUTURE MANAGEMENT OF LEGACY $P$}

Papers in this Research Topic expose a dichotomy in the concept of legacy P. In over-fertilized young soils where soils storage capacity is saturated, reducing inputs of $\mathrm{P}$ and changing the agronomic practices to utilize legacy $\mathrm{P}$ are environmentally beneficial, with no impact on the sustainability of the production system. However, in old highly weathered soils the accumulation of $\mathrm{P}$ to available pools at the expense of large legacy $\mathrm{P}$ pools should not be the focus. In the latter case a number of agronomic interventions need to be better understood to allow legacy $\mathrm{P}$ exploration and avoid the unsustainable accumulation of legacy P. Future research should generate understanding on the mechanisms involved in the dynamics of legacy $\mathrm{P}$ and how this can be manipulated and allow us to deploy the interventions, some of which are highlighted here, to maximum effect.

\section{AUTHOR CONTRIBUTIONS}

LG, GB, PP, and TG contributed equally to defining the scope for this research topic. They worked outreaching the call for submissions, and they edited the manuscripts submitted to this research topic.

Conflict of Interest: The authors declare that the research was conducted in the absence of any commercial or financial relationships that could be construed as a potential conflict of interest.

Copyright (C) 2020 Gatiboni, Brunetto, Pavinato and George. This is an open-access article distributed under the terms of the Creative Commons Attribution License (CC $B Y)$. The use, distribution or reproduction in other forums is permitted, provided the original author(s) and the copyright owner(s) are credited and that the original publication in this journal is cited, in accordance with accepted academic practice. No use, distribution or reproduction is permitted which does not comply with these terms. 